\title{
On the growth of Korean technoparks
}

By: Albert N. Link and U. Yeong Yang

Link, A.N., Yeong Yang, U. On the growth of Korean technoparks. International

Entrepreneurship and Management Journal, 14, 405-410 (2018).

https://doi.org/10.1007/s11365-017-0459-2

This version of the article has been accepted for publication, after peer review (when applicable) and is subject to Springer Nature's AM terms of use, but is not the Version of Record and does not reflect post-acceptance improvements, or any corrections. The Version of Record is available online at: $\mathrm{http://dx.doi.org/10.1007/s11365-017-0459-2}$.

\begin{abstract}
:
The Republic of Korea undertook a major initiative in the early 1970s to integrate hightechnology industry with its regional development strategy. This effort involved three phases: the development of science towns in the 1970s, the initiation of a technopolis program in the 1980s, and the establishment of science parks or technoparks in the 1990s. We focus on the third phase in this paper, and we identify empirically covariates with the employment growth of Korean technoparks. We find faster employment growth in parks established after the ICT revolution in 2000, in parks with tenants involved in more complex technology development, and in parks with more research-intensive tenants.
\end{abstract}

Keywords: science park | technopark | Korea | entrepreneurship | technology | innovation

\section{Article:}

\section{Introduction}

The government of the Republic of Korea undertook a major initiative in the early 1970s to "integrate high-technology industry and regional development" (Oh 1995). This effort involved three phases: the development of science towns in the 1970s (e.g., Daedeok Science Town in 1973), the initiation of a technopolis program in the 1980s, and the establishment of science parks or technoparks in the 1990s (Oh 2002). ${ }^{1}$ In this paper, we focus on the third phase and we identify empirically covariates with the employment growth of Korean technoparks.

The academic literature on science parks (i.e., research parks, technology parks, technoparks, etc.) is comprised primarily of case studies. Hobbs et al. (2017) show from their review of the extant literature that less than $20 \%$ of the identified publications were econometric based; more than 80\% were country-specific case studies (e.g., Kim et al. 2014; Nahm 2000; Oh and

\footnotetext{
${ }^{1}$ The word technopolis has over time taken on different meanings. Some use the word as a synonym for a science park while others use the word to refer to an encompassing science and technology infrastructure: "The term 'technopolis' is derived from the union of 'technology' and 'polis' and it means a high technology-oriented science city" (Fujita, p. 566, 1988).
} 
Yeom 2012; Park et al. 2011; Shin 2001). ${ }^{2}$ This distribution of methods for the study of science parks or technoparks is not a criticism; on the contrary, it is our view that it simply underscores the lack of country-specific park data. We attempt to take a step forward to fill that gap in this paper through our analysis of Korean technoparks.

In "Korean technoparks" Section, we describe our data on Korean technoparks, and we offer descriptive statistics related to those parks.

In "Econometric model" Section, we present the results from a simple econometric model of employment growth.

Finally, in "Empirical findings and discussion" Section, we summarize our findings and identify areas for possible future research.

\section{Korean technoparks}

The United Nations Educational, Scientific, and Cultural Organization (UNESCO) identified 18 Korean technoparks, and 17 of these 18 are the parks that define our sampling population. ${ }^{3}$

Table 1. Sampling population of Korean technoparks $(n=18)$

\begin{tabular}{|lccc|}
\hline Park & Year Established & Total Employees & Research Employees \\
\hline Gangwon Technopark & 2003 & 74 & 32 \\
Gyeonggi Daejin Technopark & 2005 & 49 & 15 \\
Seoul Technopark & 2005 & 34 & 4 \\
Inchon Technopark & 1997 & 201 & 99 \\
Gyeonggi Technopark & 1997 & 105 & 66 \\
Chungnam Technopark & 1997 & 89 & 48 \\
Chungbuk Technopark & 2003 & 159 & 52 \\
Daejeon Technopark & 2003 & 123 & 63 \\
Jeonbuk Technoark & 2003 & 99 & 21 \\
Daegu Technopark & 1997 & 165 & na \\
Gyeongbuk Technopark & 1997 & 77 & 69 \\
Pohang Technopark & 2000 & 188 & 31 \\
Ulsan Technopark & 2004 & 184 & 116 \\
Busan Technopark & 2000 & 147 & 79 \\
Gyeongnam Technopark & 2004 & 100 & 64 \\
Gwangju Technopark & 1997 & 143 & 29 \\
Jeonnam Technopark & 2003 & 146 & 50 \\
Jeju Technopark & 2010 & & 67 \\
\hline
\end{tabular}

Websites for each park. Employment data are for 2017

na not available

The technoparks in our sampling population are listed in Table 1 along with the year that they were established. As shown in Table 1, the technoparks were established by the government in

\footnotetext{
${ }^{2}$ See Link and Scott $(2003,2006,2007,2015)$ for an overview of econometric studies of science parks.

${ }^{3}$ See: $<$ http://www.unesco.org/new/en/natural-sciences/science-technology/university-industrypartnerships/science-parks-around-the-world/science-parks-in-asia/\#c99670>
} 
definable periods. Six technoparks were established in 1997, 11 in the early 2000s, and 1 in 2010 .

Our focus on employment growth as a performance metric is pragmatic and with precedents in the extant literature. In support of our focus on employment, Battelle (2013, p. 18) emphasized that "[e]mployment in [U.S.] university research parks has regional economic benefits," at the exclusion of other performance metrics. Total employment and research employment are the available measures for 17 of the 18 technoparks.

\section{Econometric model}

The empirical goal of this paper is to investigate cross-technopark differences in employment growth over time. The dependent variable in our model is the number of employees divided by the number of years since the park was established: emp/year.

We focused on four independent variables. The first variable documents the start of the so-called Information and Communications Technology (ICT) revolution: ICT. The variable ICT is a binary variable equal to 1 for all technoparks established after 2000, and 0 otherwise. We hypothesize that employment growth will be greater in the ICT new millennium period because of greater research speed and thus greater technological advancement.

The second independent variable measures the complexity of the research performed in the technopark: complex. We could determine from each technopark's website the research areas of concentration in the park; the variable complex is simply a count of the reported research areas. For example, the reported main research areas in Gangwon Technopark are advanced materials science and local industry support. Thus, for that park the variable complex equals 2 . We hypothesize that the more complex the research performed in a technopark, as so measured, the greater will be employment growth. Simply, greater complexity will require a more diverse employment force and greater human capital.

The third independent variable is researcher employment as a percentage of total employment: resemp/emp. Our hypothesis is that for those parks that are more research intensive, as measured by this employment percentage, the greater will be its growth over time as measured by emp/t. New technologies are combinations of previous technologies, thus the more research intensive the park, the more fruitful will be its output and thus its growth.

The fourth independent variable is the distance in miles the park is from the nearest university: distance. Our spatial focus builds on the work of Link and Scott (2006) who found that the closer a park is to its university the greater its access to the university's human and technical capital and thus the greater is employment growth in the park.

Descriptive statistics on these five variables are in Table 2. 
Table 2. Descriptive statistics on the variables $(n=17)$

\begin{tabular}{|lccc|}
\hline Variable & Mean & Standard Deviation & Range \\
\hline emp & 122.53 & 49.43 & $34-201$ \\
emp/t & 8.51 & 4.57 & $2.83-20.86$ \\
ICT & 0.59 & 0.51 & $0 / 1$ \\
complex & 3.59 & 2.15 & $1-9$ \\
resemp/emp & 0.41 & 0.13 & $0.12-0.63$ \\
distance & 5.57 & 5.19 & $0-21.5$ \\
\hline
\end{tabular}

\section{Empirical findings and discussion}

Our regression results from four specifications of our model are presented in Table 3. The models are simplistic owning to us having only 17 technoparks in our sampling population. The first two models in columns (1) and (2) include all four of the dependent variables. The model in column (1) uses emp/t as the dependent variable, and the model in column (2) uses $\ln (\mathrm{emp} / \mathrm{t}$ ) as the dependent variable. The variable distance is not statistically significant in either of these two specifications, and thus the corresponding models are re-estimated excluding that variable.

Technoparks established after the ICT revolution in 2000 enjoy greater employment growth, as hypothesized, although the estimated regression coefficient on ICT is statistically significant at only the 0.15-level in the specification in column (1); it is statistically significant at the 0.05level in the specification in column (2). The estimated coefficients on complex are not statistically significant at conventional levels, but the estimated coefficients on resemp/emp are, as hypothesized. The distance variable is not statistically significant in either specification.

Table 3. Regression results ( $n=17$, standard errors in parentheses)

\begin{tabular}{|c|c|c|c|c|}
\hline Variable & (1): emp/t & (2): $\ln (e m p / t)$ & (3): emp/t & (4): $\ln (e m p / t)$ \\
\hline \multirow[t]{2}{*}{$I C T$} & $4.48^{*}$ & $0.47 * * *$ & $4.72 * * *$ & $0.52 * * *$ \\
\hline & (2.13) & $(0.22)$ & $(2.02)$ & $(0.22)$ \\
\hline \multirow[t]{2}{*}{ complex } & 0.58 & 0.09 & $0.77 *$ & $0.12 * * *$ \\
\hline & $(0.56)$ & $(0.06)$ & $(0.48)$ & $(0.05)$ \\
\hline \multirow[t]{2}{*}{ resemp/emp } & $12.73 *$ & $1.53 * *$ & $13.54 * *$ & $1.65 * *$ \\
\hline & (7.98) & $(0.83)$ & $(7.76)$ & $(0.83)$ \\
\hline \multirow[t]{2}{*}{ distance } & 0.16 & 0.03 & - & - \\
\hline & $(0.22)$ & $(0.02)$ & & \\
\hline \multirow[t]{2}{*}{ Intercept } & -2.31 & $0.66^{*}$ & -2.60 & 0.62 \\
\hline & $(4.10)$ & $(0.43)$ & $(4.01)$ & $(0.43)$ \\
\hline $\mathrm{R}^{2}$ & 0.44 & 0.54 & 0.41 & 0.50 \\
\hline F-level & $2.31 *$ & $3.50 * * *$ & $3.02 * *$ & $4.25^{* * *}$ \\
\hline
\end{tabular}

**** significant at .01-level, ${ }^{* * *}$ significant at .05-level, ${ }^{* *}$ significant at .10-level, ${ }^{*}$ significant at .15 -level

When the variable distance is deleted from these models, as reported in columns (3) and (4), the estimated coefficients on all of the other three variables become statistically significant. The correlation coefficient between complex and distance is 0.493 , and it is statistically significant at the .05-level, which might explain why the estimated coefficients on complex in columns (1) and (2) are statistically insignificant. 
While our empirical findings support our hypotheses, caution should be exercised in generalizing from our findings. First, our sample, while representative of Korean technoparks, is small and thus our empirical models are necessarily simplistic. Second, available data on Korea's technoparks are limited; a point that Hobbs, Link, and Scott (2017) have made about park studies in most countries. And third, our analysis is, to the best of our knowledge, the first to examine growth characteristics of Korea's technoparks; thus, there are no benchmarks to which we can compare our findings. Keeping this third caveat in mind, our findings do suggest that future technoparks established in the ICT new millennium period might even enjoy greater employment growth. Based on the regression results in column (3), parks established in the ICT new millennium have grown an average of nearly 5 employees per year, or nearly $4 \%$ against the mean number of employees of 122.5 .

Future research, regardless of the country focus, should in our view explore other performance metrics besides employment growth. And possibly, future research should also include longitudinal perspectives in addition to more refined cross-sectional analyses.

\section{References}

Battelle Technology Partnership Practice. (2013). Driving regional innovation and growth. Columbus: Battelle.

Fujita, K. (1988). The Technopolis: high technology and regional development in Japan. International Journal of Urban and Regional Research, 12, 515-680.

Hobbs, K. G., Link, A. N., \& Scott, J. T. (2017). Science and technology parks: an annotated and analytical literature review. Journal of Technology Transfer. doi:10.1007/s10961-0169522-3.

Kim, H., Lee, Y.-S., \& Hwang, H.-R. (2014). Regionalization of planned S\&T parks: the case of Daedeok S\&T park in Daejeon, South Korea. Environment and Planning C: Government and Policy, 32, 843-862.

Link, A. N., \& Scott, J. T. (2003). U.S. science parks: the diffusion of an innovation and its effects on the academic mission of universities. International Journal of Industrial Organization, 21, 1323-1356.

Link, A. N., \& Scott, J. T. (2006). U.S. university research parks. Journal of Productivity Analysis, 25, 43-55.

Link, A. N., \& Scott, J. T. (2007). The economics of university research parks. Oxford Review of Economic Policy, 23, 661-674.

Link, A. N., \& Scott, J. T. (2015). Research, science, and technology parks: vehicles for technology transfer. In A. N. Link, D. S. Siegel, \& M. Wright (Eds.), The Chicago handbook of university technology transfer and academic entrepreneurship. Chicago: University of Chicago Press.

Nahm, K.-B. (2000). The evolution of science parks and metropolitan development. International Journal of Urban Sciences, 4, 81-95. 
Oh, D.-S. (1995). High-technology and regional development policy: an evaluation of Korea's technopolis programme. Habitat International, 19, 251-267.

Oh, D.-S. (2002). Technology-based regional development policy: case study of Taedok science town, Taejon Metropolitan City, Korea. Habitat International, 26, 213-228.

Oh, D.-S., \& Yeom, I. (2012). Daedeok innopolis in Korea: from science park to innovation cluster. World Technopolis Review, 1, 141-151.

Park, H., Kang, K.-N., \& Kim, H. R. (2011). Development of biotechnology clusters: the case of Daedeok science town, Korea. Asian Journal of Technology Innovation, 19, 201-218.

Shin, D.-H. (2001). An alternative approach to developing science parks: a case study from Korea. Papers in Regional Science, 80, 103-111. 